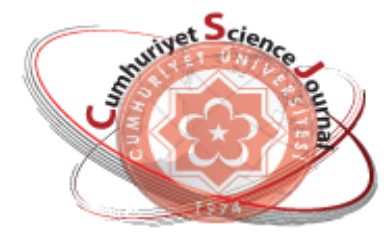

e-ISSN: $2587-246 X$

ISSN: 2587-2680

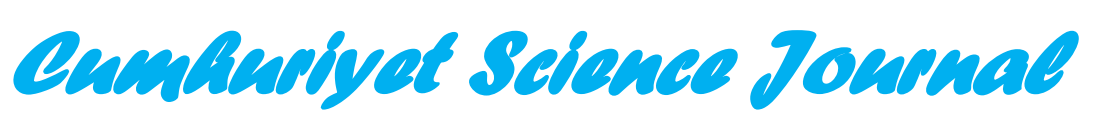

esJ

Cumhuriyet Sci. J., Vol.39-3(2018) 766-770

\title{
The Determination of the Specific Capacitance of Mercury Based Copper Oxide Layered Superconductor at Superconducting State
}

\author{
Özden ASLAN ÇATALTEPE \\ İstanbul Gedik University, Engineering Faculty, İstanbul, TURKEY
}

Received: 25.05.2018; Accepted: 10.07.2018

http://dx.doi.org/10.17776/csj.427219

\begin{abstract}
Mercury based copper oxide layered high temperature superconductor, which consists of superconductor-insulator-superconductor (SIS) layers, can be considered as a stack of nearly ideal, intrinsic Josephson junctions (IJJ). The SIS junction, where the electrical field is confined, topologically resembles a parallel-plate capacitor. As is known, the coupling between junctions in superconductors is capacitive. Hence, the determination of the specific capacitance $\left(C_{s}\right)$ of the IJJ at the superconducting state has a crucial importance in order to give information about superconductivity mechanism. In this study, the $C_{s}$ values of the investigated sample have been calculated by means of the critical current density, $J_{c}$ and plasma frequency, $\omega_{p}$ that have been obtained from magnetic measurements taken at the below temperatures than the critical transition temperature, $T_{c}$. Moreover, $C_{s}$ values at superconducting temperature have been compared to that of the normal temperature.
\end{abstract}

Keywords: Specific capacitance, intrinsic Josephson junctions, copper oxide layer.

\section{Süperiletken Durumda Cıva Bazlı Bakır Oksit Katmanlı Süperiletkenin Özgül Kapasitanslarının Tespiti}

\begin{abstract}
Özet. Süperiletken-yalıtkan-süperiletken (SYS) katmanlardan oluşan cıva bazlı bakır oksit katmanlı yüksek sıcaklık süperiletkenleri neredeyse ideal, asli Josephson kavşakları dizisi olarak göz önüne alınabilir. Elektrik alanı hapseden bir SYS kavşağı, topolojik olarak paralel plakalı bir kapasitöre benzer. Bilindiği üzere, süperiletkenlerdeki kavşaklar arasındaki kuplaj kapasitiftir. Bundan dolayı, süperiletken durumda özgül kapasitans, $C_{s}$ 'nin tespiti süperiletkenlik mekanizması hakkında bilgi elde etmek için çok büyük bir öneme sahiptir. Bu çalışmada, incelenen örneğin $C_{s}$ değerleri kritik geçiş sıcaklığı olan $T_{c}$ 'den daha düşük sıcaklıklarda yapılan manyetik ölçümlerden elde edilen kritik akım yoğunluğu, $J_{c}$ ve plazma frekansı $\omega_{p}$ değerleri aracılığıyla elde edildi. Ayrıca süperiletken sıcaklıkta $C_{s}$ değerleri normal durumdaki $C_{s}$ değerleriyle de karşılaştırılmıştır
\end{abstract}

Anahtar Kelimeler: Özgül kapasitans, asli Josephson kavşakları, bakır oksit katmanları.

\section{INTRODUCTION}

Copper oxide layered high-temperature superconductors have a common structure in which superconducting copper oxide layers are separated by a thin insulating layer. Copper oxide layers are coupled together by Josephson tunnelling between adjacent layers. According to the experimental evidences, cuprates (copper oxide layered samples) such as $\mathrm{Bi}-\mathrm{Sr}-\mathrm{Ca}-\mathrm{Cu}-\mathrm{O}$, $\mathrm{Y}-\mathrm{Ba}-\mathrm{Cu}-\mathrm{O}, \mathrm{Tl}-\mathrm{Ba}-\mathrm{Ca}-\mathrm{Cu}-\mathrm{O}$ and $\mathrm{Hg}-\mathrm{Ba}-\mathrm{Ca}-\mathrm{Cu}-\mathrm{O}$ behave like stacks of superconductor-insulatorsuperconductor (SIS) intrinsic Josephson 
junctions (IJJ) [1,2]. Because of this property, the Josephson junctions topologically resemble a parallel plate capacitor. SIS junctions are used as SIS mixer for radio astronomical spectroscopy in millimeter and sub-millimeter range, and environmental science. [3,4]. In order to determine the specific capacitance $\left(C_{s}\right)$ of the IJJ at superconducting state, the most used experimental method is direct microwave experiment [5]. In this context, the determination of the specific capacitance of the superconducting sample has a crucial importance in order to understand the superconducting mechanism. In this study, the $C_{s}$ values of the $\mathrm{HgBa}_{2} \mathrm{Ca}_{2} \mathrm{Cu}_{3} \mathrm{O}_{8+\mathrm{x}}$ (Hg-1223) superconductor have been investigated both at superconducting and non-superconducting states for the first time. $C_{s}$ value at superconducting state has been calculated by means of the critical current density, $J_{c}$ and plasma frequency, $\omega_{p}$ that have been obtained by the magnetic measurements. At nonsuperconducting state, $C_{s}$ values have been obtained by dielectric measurements. At superconducting state, it has been determined that the specific capacitance values of the samples are independent from both oxygen doping ratio and temperature. Also, it has been determined that the specific capacitance value of the Josephson junction at the non-superconducting state is much bigger than that of the superconducting state. Moreover, the oxygen doping procedure affects the specific capacitance value at room temperature. From this point of view, determination of the specific capacitance of the Josephson junction of the $\mathrm{Hg}$-based cuprate sample has a key role for capacitor and memory device applications.

\section{SYNTHESIS OF HG-1223 SAMPLES}

The Hg-1223 samples have been synthesized by using the two-step solid state reaction technique. In the technique the precursor material with the same nominal composition of $\mathrm{Ba}_{2} \mathrm{Ca}_{2} \mathrm{Cu}_{3} \mathrm{O}_{x}$ (reactant material) has been prepared with four nine purity compounds of $\mathrm{BaO}, \mathrm{CaO}$ and $\mathrm{CuO}$, and then heating them at $1340{ }^{\circ} \mathrm{C}$ for $10 \mathrm{~h}$ in oxygen environment. The reactant material and the high-purity $\mathrm{HgO}$, which has been put in a smaller diameter test tube, have been both placed in the first tube, which has been finally evacuated and sealed. In the second step, the sealed quartz tube has been placed horizontally in a furnace and heated at a rate of $1.5^{\circ} \mathrm{C} / \mathrm{min}$ to $940{ }^{\circ} \mathrm{C}$ for $3 \mathrm{~h}$. At the end of the preparation method, the "underdoped mercury based sample" has been obtained. In order to obtain the optimally oxygen doped $\mathrm{Hg}$ 1223 superconducting material, the sample has been annealed in oxygen atmosphere at $300^{\circ} \mathrm{C}$, well below the decomposition temperature of $\mathrm{HgO}$, for $10 \mathrm{~h}$. It has been determined that the result of oxygen annealing process, holes are doped to the superconducting system which causes a change in the electronic excitations. The process, by which the optimum oxygen doped sample has been synthesized, has been relatively decided to the specimen response to magnetization measurements such as magnetic susceptibility versus temperature and magnetic hysteresis. Hence, the critical parameters, i.e. the critical transition temperature $\left(T_{c}\right)$, the critical current density $\left(J_{c}\right)$ and the critical magnetic field $\left(H_{c}\right)$, which are important indicator in order to determine optimum oxygen level, are higher values than under-doped sample. For example, the critical transition temperatures for optimally and under-oxygen-doped $\quad \mathrm{HgBa}_{2} \mathrm{Ca}_{2} \mathrm{Cu}_{3} \mathrm{O}_{8+\mathrm{x}}$ superconductors have been determined as $137.3 \mathrm{~K}$ and $123 \mathrm{~K}$, respectively [6].

\section{THEORETICAL BACKGROUND}

The primitive cell of the Hg-based cuprate superconductor contains three superconducting copper oxide planes separated by insulating layers. Hence, this structure is considered as an IJJ array (Figure 1). The main Josephson plasma excitation modes in weakly Josephson coupled layered superconductors are the longitudinal along the c-axis and transversal plasma modes in the ab-plane. [7]. In high temperature cuprate superconductors, Bose -Einstein Condensation (BEC) occurs in copper oxide layers (i.e. ab planes). At superconducting state, BEC of Cooper pairs in the $\mathrm{CuO}_{2}$ layers extends through the all copper oxide layers with the plasma resonance frequency. In other words, superconductivity 
occurs in connection with a crossover from twodimensional (2D) to 3D transport below the critical transition temperature, $T_{c}$ [8-12]. So that, the perfectly coupled layered mercury-based superconducting material has been proposed to serve as an example of exhibition of 3D-spatial BEC [6]. It means that the longitudinal (Josephson) plasma frequency $\left(\omega_{j}\right)$ along the caxis equals to the transversal plasma frequency, $\left(\omega_{p}\right)$ in ab-plane, $\omega_{j}=\omega_{p}[13]$.

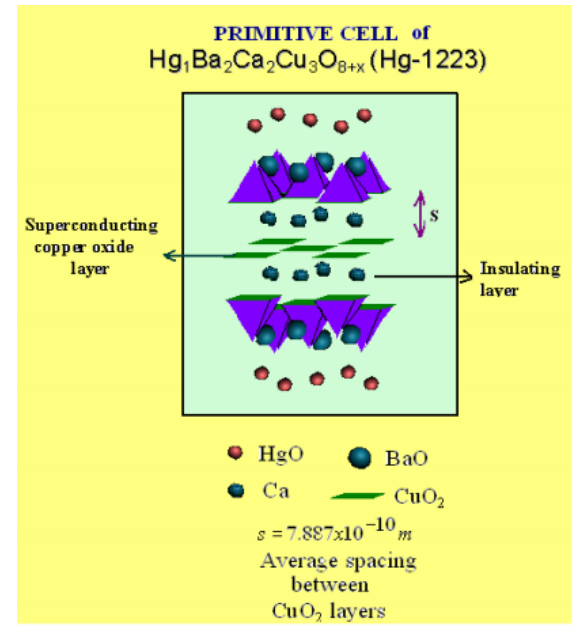

Figure 1. The primitive cell of mercy based (Hg-1223) superconductor [14].

Superconducting Josephson junctions, which exhibit solitonic behavior, can be described by Sine-Gordon equation. As is known that in superconducting state, solitons are quantum of magnetic flux. The production and storage of the solitons give very important knowledge about the investigated systems. The solution of the SineGordon equation give us the information about the Josephson plasma frequency, $\omega_{j}$ [15-19].

$$
\omega_{j}=\sqrt{2 e J_{c} /\left(C_{s} \hbar\right)}
$$

where $J_{c}, C_{s}, \hbar$, and $e$ are the critical current density, specific capacitance of the IJJ, Planck constant and the charge of the electron, respectively. In order to calculate the specific capacitance of IJJ, the plasma frequency, $\omega_{p}$ and the critical current density, $J_{c}$ values are needed. $\omega_{p}$ and $J_{c}$ values for optimum and under oxygen doped samples have been obtained from magnetic hysteresis curves. The dynamic hysteresis measurements of mercury cuprates been performed by the Quantum Design SQUID susceptometer, model MPMS-5S. The measurements of magnetic hysteresis have been made around the lower critical magnetic field, $H_{c l}$ [6].

\section{RESULTS}

The $C_{s}$ values of the IJJ have been calculated by means of Equation 1. The related $\boldsymbol{\omega}_{\boldsymbol{p}}, J_{c}$ and $C_{s}$ values of the samples have been given Table1.

Table 1. $\boldsymbol{\omega}_{\boldsymbol{p}}, J_{c}$ and $C_{s}$ values of the under and optimally oxygen doped samples.

\begin{tabular}{llll}
\hline \hline$T(\mathrm{~K})$ & $\omega_{p}(\mathrm{~Hz})$ & $J_{c}\left(\mathrm{~A} / \mathrm{m}^{2}\right)$ & $C_{s}\left(\mathrm{mF} / \mathrm{m}^{2}\right)$ \\
\hline \hline 4.2 (opt.) & $5.217 \times 10^{14}$ & $10^{12}$ & 11.15 \\
27 (opt.) & $2.09 \times 10^{14}$ & $1.62 \times 10^{11}$ & 11.26 \\
77 (opt.) & $5.217 \times 10^{13}$ & $10^{10}$ & 11.15 \\
7 (und.) & $31.4 \times 10^{12}$ & $1.43 \times 10^{11}$ & 11.15 \\
\hline
\end{tabular}

The capacitance values of the optimally and under oxygen doped samples at room temperature values, which have been calculated by means of the capacitive reactance, $X_{c}$ and frequency, $f$ $\left(C=1 / 2 \pi f X_{c}\right)$, have been performed by Hewlett Packard 4192A impedance analyzer [20]. The area of the copper oxide layers (ab-plane), which is necessary for calculating the $C_{s}$ value, has been calculated by the lattice parameter. The lattice parameters of both the optimally and under doped Hg-based superconductors, which have been calculated by means of XRD data, have been found as $a=b=3.8684 \times 10^{-10} \mathrm{~m}$ and $a=b=3.8328 \times 10^{-10} \mathrm{~m}$, respectively [14]. The variation of the capacitance and specific capacitance values with frequency of the under and optimally oxygen doped samples at room temperature has been listed in Table 2 . 
Table 2. Capacitance and specific capacitance value of the under and optimally doped sample the at room temperature.

\begin{tabular}{lll}
\hline \hline \multicolumn{3}{l}{ Under doped sample } \\
$f(\mathrm{kHz})$ & $C(F)$ & $C_{s}\left(F / \mathrm{m}^{2}\right)$ \\
\hline 5 & $5.502 \times 10^{-9}$ & $0.375 \times 10^{11}$ \\
40 & $2.199 \times 10^{-10}$ & $0.149 \times 10^{10}$ \\
80 & $6.478 \times 10^{-11}$ & $0.441 \times 10^{9}$ \\
500 & $3.58 \times 10^{-12}$ & $0.244 \times 10^{8}$ \\
$3 \times 10^{3}$ & $8.464 \times 10^{-13}$ & $0.576 \times 10^{7}$ \\
$1 \times 10^{4}$ & $5.168 \times 10^{-13}$ & $0.352 \times 10^{7}$ \\
\hline
\end{tabular}

\section{DISCUSSION AND CONCLUSIONS}

As is known, the design restrictions for high frequency devices and SQUIDs depend on the properties of the specific capacitance of the IJJ. Hence, the study has been devoted to the specific capacitance values of the various oxygen doped mercury based samples which have been investigated at superconducting and nonsuperconducting state for the first time. It has been found that the specific capacitance quantities of the samples at superconducting state, which are independent from oxygen doping ratio and temperature, have approximately same value as 11 $m F / m^{2}$. This result is consistent with the study on small-capacitance Josephson junctions in literature where the specific capacitance, $C_{s}$ is on the order of $20-100 \mathrm{fF} / \mu \mathrm{m}^{2}$ (i.e. $20-100 \mathrm{mF} / \mathrm{m}^{2}$ ) $[21,22,23]$. Also, it has been determined that the specific capacitance values of the Josephson junctions at the non-superconducting state are much bigger than that of the superconducting state. Moreover, the oxygen doping procedure affects the specific capacitance values at room temperature. From this point of view, the determination of the specific capacitance of the intrinsic Josephson junction of the $\mathrm{Hg}$-based copper oxide layered has a key role for capacitor, memory device applications, single electron transistors and high frequency devices.

\section{ACKNOWLEDGEMENT}

This research has been supported by İstanbul Gedik University Scientific Research Projects Coordination Department with the Project No. GDK201702-BA004

\begin{tabular}{ccc}
\hline \hline \multicolumn{3}{c}{ Optimally doped sample } \\
$f(\mathrm{kHz})$ & $\mathrm{C}(\mathrm{F})$ & $C_{s}\left(\mathrm{~F} / \mathrm{m}^{2}\right)$ \\
\hline 5 & $1.639 \times 10^{-10}$ & $0.109 \times 10^{10}$ \\
40 & $9.411 \times 10^{-12}$ & $0.629 \times 10^{8}$ \\
80 & $5.225 \times 10^{-12}$ & $0.349 \times 10^{8}$ \\
800 & $2.88 \times 10^{-12}$ & $0.193 \times 10^{8}$ \\
$3 \times 10^{3}$ & $2.702 \times 10^{-12}$ & $0.181 \times 10^{8}$ \\
$1 \times 10^{4}$ & $2.567 \times 10^{-12}$ & $0.172 \times 10^{8}$ \\
\hline
\end{tabular}

\section{REFERENCES}

[1]. Kleiner R. and Müller P., Intrinsic Josephson effects in high-Tc superconductors, Phys. Rev. B ö49, (1994) 1327.

[2]. Ueda S., Okutsu T., Kubo Y., Ishii S., Tsuda S., Yamaguchi T., Horii S., Shimoyama J., Kishio K., Takano Y., Intrinsic Josephson properties in $(\mathrm{Hg}, \mathrm{Re}) \mathrm{Ba}_{2} \mathrm{Ca}_{3} \mathrm{Cu}_{4} \mathrm{O}_{10+\delta}$ single crystals, Physica C: Superconductivity, Volume 468, Issues 15-20, (2008) 1925-1928.

[3]. Klapwijk T.M., Dieleman P., and de Graauw M.W.M., Pushing the operating range of SIS mixers into the $\mathrm{THz}$ regime, Supercond. Sci.Technol., vol. 10, no. 12, (1997) 876-879.

[4]. Dolata R., Scherer H., Zorin A. B., and Niemeyer J., Single-charge devices with ultrasmall $\mathrm{Nb} / \mathrm{AlOx} / \mathrm{Nb}$ trilayer Josephson junctions, J. Appl.Phys., vol. 97, no. 5, (2005) 54501.

[5]. Yadranjee Aghdam P., Rashid H., Pavolotsky A., Desmaris V.,. Meledin D. and Belitsky V., Specific Capacitance Dependence on the Specific Resistance in $\mathrm{Nb} / \mathrm{Al}-\mathrm{AlOx} / \mathrm{Nb}$ Tunnel Junctions, IEEE Transactions on Terahertz Science and Technology, vol. 7, no. 5, (2017).

[6]. Özdemir Z. G., Aslan Ö. and Onbaslı Ü., Terahertz oscillations in mercury cuprate superconductors, Pramana-J. Phys. 73(4), (2009) 755-763.

[7]. Machida M. and Tachiki M., Terahertz electromagnetic wave emission by using intrinsic Josephson junctions of high-Tc 
superconductors, Curr. Appl. Phys., 341 (2001).

[8]. Adhikari S. K. et al., Superconductivity as a Bose-Einstein Condensation?, Physica C, , 233 (2000) 341-348.

[9]. Almaas E. and Stroud D., Dynamics of a Josephson array in a resonant cavity, Phys. Rev. B 65, (2002) 134502.

[10]. Tornes I. and Stroud D., Possibility of caxis voltage steps for a cuprate superconductor in a resonant cavity, Phys. Rev. B 68, (2003) 052512.

[11]. Tornes I. and Stroud D., Long Josephson junction in a resonant cavity, Phys. Rev. B 71, (2005) 144503.

[12]. Anderson P.W., c-Axis Electrodynamics as Evidence for the Interlayer Theory of HighTemperature Superconductivity, Science 279, (1998) 1196.

[13]. Aslan Çataltepe Ö., New method to forecast the optimum lateral size for mesa structure in superconductors International Journal of Modern Physics B, Vol. 30, No. 26 (2016) 1-9.

[14]. Aslan Ö., Güven Özdemir Z., Keskin S.S. and Onbaşlı Ü., The chaotic points and XRD analysis of Hg-based superconductors, Journal of Physics: Conference Series, 153, (2009)1-9.

[15]. Josephson, B.D., Possible new effects in superconductive tunnelling, Physics Letters, 1, (1962) 251.

[16]. Pederson, N.F., Solitons in Josephson transmission lines, in Solitons, S.E. Trullinger, V.E. Zakharov, and V.L. Prokovsky, eds., North-Holland, Amsterdam (1986).

[17]. Riazi N., Dynamics of solitons in inhomogeneous Josephson junctions, International Journal of Theoretical Physics January Volume 35, Issue 1, (1996)101113.

[18]. Mints R.G., Snapiro I.B., Josephson vortex Cherenkov radiation, Physical Review B, 52/13, (1994).

[19]. Jung P., Nonlienar effects in Superconducting Quantum Interference
Meta Atoms, Scientific Publishing, pp 41 (2014).

[20]. Güven Özdemir Z., Aslan Çataltepe Ö., Onbaşlı Ü., Impedance and dielectric properties of mercury cuprate at nonsuperconducting state, International Journal of Modern Physics B, 29, (2015) 1550205.

[21]. Meckback J.M., Superconducting Multilayer Technology for Josephson Devices, Scientific Publishing, pp 63,126 (2013).

[22]. Watanabe M., Haviland D. B., SmallCapacitance Josephson Junctions: OneDimensional Arrays and Single Junctions, Condensed Matter, Mesoscale and Nanoscale Physics, (2003). arXiv:condmat/0301340v1.

[23]. Gustafsson D., Bauch T., Nawaz S., Mumtaz M., Signorello G., Lombardi F., Low capacitance HTS junctions for single electron transistors, Physica C 470 (2010) pp. S18 